\title{
「死の行進（?）」一赤道直下のマイナス
}

\section{1. 懐中電灯をもって山登り}

誰かの身支度をしているゴソゴソという音に，あわ てて枕元の時計を見た。「2時だよ」という声は村井教 授(東大生研)。今日も張り切っている。昨日, 一番疲 れていたアブドラ (Mr. Abdul Cheds Sahamat, Dept of Development, State Planning Unit, Sarawak) が 咳をしている。「頭が痛い」という声は越智さん (UNCRD : 国連地域開発センター), 高山病に違いな いとリュックの中から「風邪薬ルル」を渡したら，村 井教授，アブドラからも手が伸びて来た。午前 2 時 30 分 open, 午前 4 時 close と書かれてあったレストラン でスープとビスケットの朝食, 夕食は中華のフルコー スを食べたばかりという記憶の中, 熱い液体を流し込 む。今日は, 久しぶりに富士山より高い山へ登るとい う気持ちの昂りを感じながら, 懐中電灯のスイッチを 押した。海拢 $3,300 \mathrm{~m}$ の洒落たコテージ，LABAN
RATA RESTHOUSE を午前 3 時に出発， $3,810 \mathrm{~m} の$ 森林限界の上, SYAT SYAT という最も高地の山小 屋が構えている前, 4 時20分, 出発して初めて大休止 をとった。少しづつ, 空と山の境界がハッキリとして 来て, 朝が来ることを教えてくれている。

突然，一枚岩が出現してきた。立派なロープがあり 順々につかまって, 登っていく。懐中電灯のあかりで はこの岩の大きさも傾斜もわからない。昔を思い出し ながら，フリークライミングで登りはじめたら，丸み を扔びた花崗岩は延々と続いている。気持ち良くフリ クション(靴と岩の摩擦)の利く岩肌を登っていくと, ガイドブックにあった「Summit Plateau」に出た。奇 怪な形をしたドンキーイヤー, アグリシスター，鋭い ピークのキナパルサウス, 懐中電灯が作る長い人影の 先，頂上はまだ見えない。

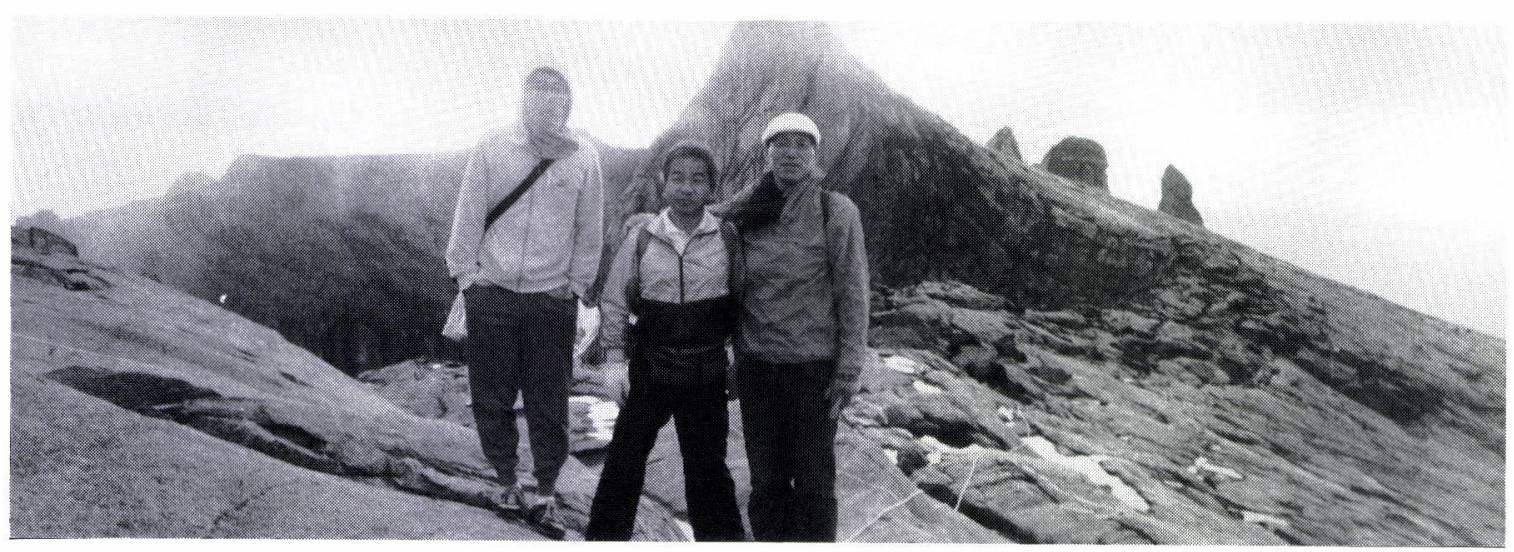

写真 1 Summat Plateauにて

*(侏パスコ

「写真とリモートセンシング」Vol. 31，No. 1. 1992 


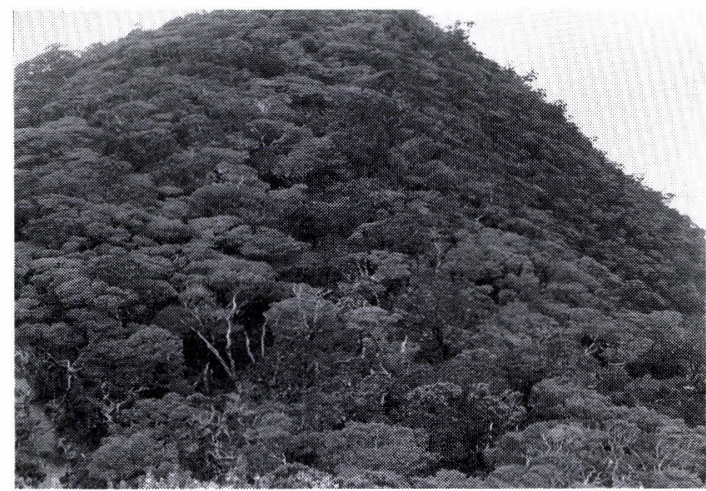

写真 2 シャクナゲ科林

\section{TROPICAL ECO-SYSTEM WORKSHOP}

リゾートホテル Tanjung Beach Hotel の会議室 (夜 はバーになる), 椎貝教授 (筑波大) の Keynote Address でTropical Eco-system workshopは始 まった。由来も参加メンバーがどういう国から来ると いう予備知識なしに飛び込んだ私は, いつもながらの ヒゲ面のDr. A. N. CHOUDHURY (BANGLADESH）の顔を見てホットした。

伐採した東南アジアの熱帯林の $90 \%$ も輸入している のは日本であると「ジャパン・バッシング」を受けは じめても, 熱带林消失のペースは変わらず, 夕イ, フィ リピン, マレーシア, インドネシアと進んで, 世界中 が熱帯林の再生をと動きはじめたのが1980年代後半で ある。この Tropical Eco-system workshop は IHP (International Hydrological Programme), ISY (International Space Year) 及び UNCRDの共同で, 熱帯林消失が生ずる様々な現象を把握するためにり モートセンシングの研究者と消失による水文学的な機 構の変化を究める水文学研究者が共通の場で討論する こと, 及び熱帯林を観察することを目的として開催さ れた。

日本から参加した村井教授, 越智さんと私に, 夕イ から参加した上甲氏 (宇宙開発事業団)，細村教授 (AIT) はリモートセンシンググループであり，椎貝教 授, 竹内教授 (山梨大) などは水文学グループである。 水文学グループはタイ国チャオプラャ川流域における 降雨量変動と流出解析の関係を発表され, Dr. A. M. CHOUDHURY は特にバングラディッシュを襲った
サイクロンをモニタリングした結果について発表し た。両事例共に土石流, 高波による被害が多数出たこ ともあり，切実な問題提起であった。村井教授は文部 省の重点領域「Eco-climate map」の紹介をし，伝統 的な焼畑耕作と商業的な焼畑を区別して対応する必要 性を述へられた。論文に眼を通していたら,「自己紹介」 をと。大いに慌てた。

\section{3. 熱 帯 林}

熱帯林というと日本人はすぐに, ツル性植物が繁茂 し，樹高40～50m の林床は毒蛇，トカゲが俳徊する ジャングルをイメージする。

実際の熱帯林はというと図-1にあるように上層木 と下層木が歴然としており，樹冠うっぺい度（単位面 積当りの樹冠投影面積の占める割合）が高いため, 下 層木の下の林床植生は貧弱であり, 林内は暗くても, 林間は見通しもよい。これは，太陽光が上層木の樹冠 により遮られて，植生成育に必要なエネルギーが不足 していることと，林床に生息するシロアリに代表され る小動物群が大量の有機物を分解してくれることにも よる。

図-1に示されている低地多雨林, 亜山地多雨林の境 界は明確でない。サバ州で実際に車で ground truth に 入ると，沿道の二次林では全く区別がつかない。低地 多雨林, 覀山地多雨林, 共通に優占するのはフタバギ

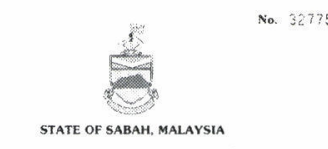

\section{Kinabalu $\mathscr{P}_{a r k}$}

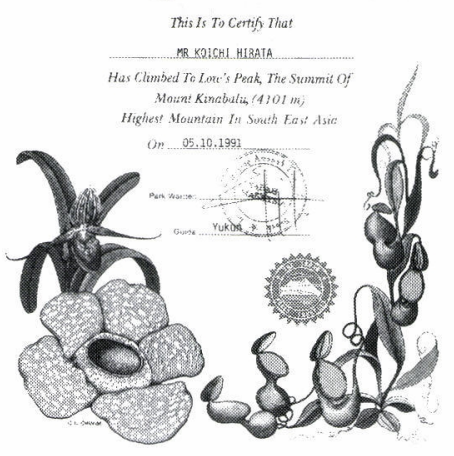

写真 3 キナバル山登頂証明書 


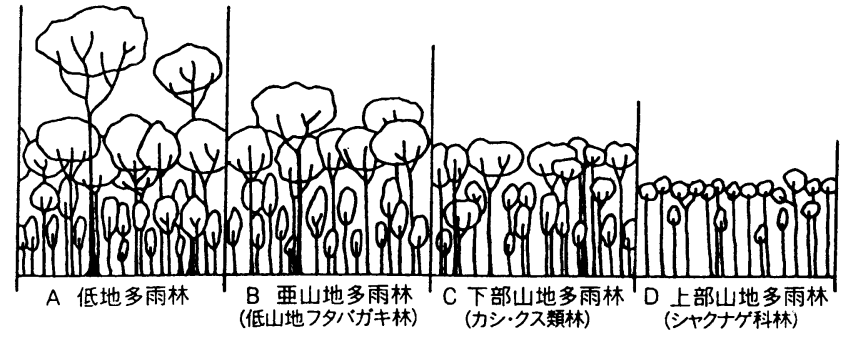

図- 2 キナバル山の植生垂直分布

科（Dipterocarpaceae）であり，ボルネオ島の低地多 雨林は Shorea albida (アラン林) が優占していること が亜山地多雨林との違いである。

海抜 $1,000 \mathrm{~m}$ 位を境界として，下部山地多雨林が分 布してカシ，クス類が優占している。この林内に入る と沖縄県の西表島の照葉樹林に見られる植生と共通し ているが, 熱帯地方では高湿度がもたらす雲霧帯と呼 ばれる，着生植物のシダ，ランが幹や枝をおおいつく している。上部山地多雨林は $2,000 \mathrm{~m}$ 位から森林限界 $(3,800 \mathrm{~m}$ 位 $)$ までに分布しシャクナゲが優占する林分 である。

\section{4. サバ州の熱帯林}

サバ州の州都 Kota Kinabalu から Beaufort までは バスで 2 時間，モクマオウの並木，典型的な二次植生 であるオオバギ，サゴヤシが点在する低地多雨林，川 にかかる橋の上からはマングローブ林の帯を観察し た。

Beaufort で森林鉄道に乗り替えて, 低地多雨林の中 に入ったが，周囲は殆どが二次林しかない。陽当たり のよい斜面にはバショウ科の植生が Pioneer Plant と して見られ，陰性の谷斜面はツル性植物が樹冠表層を おおって，二次林ということがすぐわかる。一部の急 な尾根筋に残った原生林も高さはせいぜい20～30m であった。

図- 2 は MT. KINABALU NATIONAL PARK の Headquatersに展示されていた Mt. KINABALUの 植生垂直分布をスケッチしてきたものである。

キナバル山の国立公園事務所が位置する $1,530 \mathrm{~m}$ ま では，下部山地多雨林が登山道の両側に続いて，林内 はラン, シダが付着した日本にも分布するシイ, カシ, マテバシイの近縁種がオトギリソウ科のフクギ，テリ 八ボク等と混在し， $3 \sim 4 \mathrm{~m}$ の高さのシダ植物のへゴ

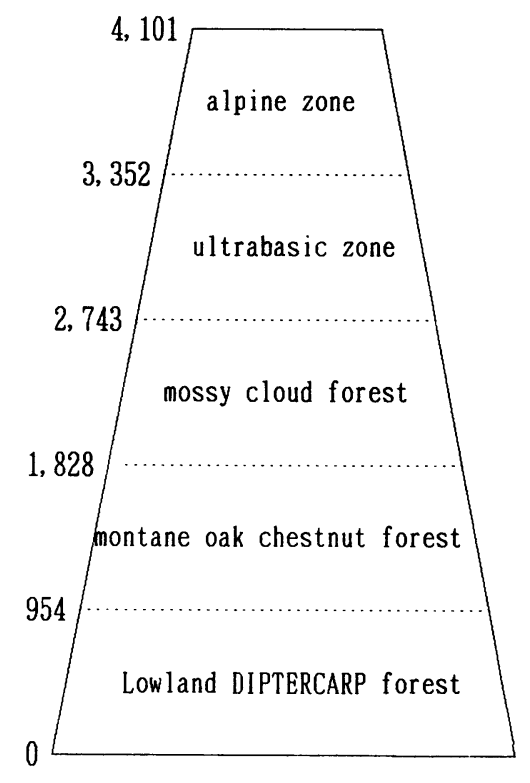

図-1 マレー半島の高度による植生変化 ${ }^{1)}$

が出現する。

上部山地多雨林に入るとナンョウスギが見られる シャクナゲ樹林である。シャクナゲは一種のみ橙色の 花を確認，2,400m から高山にかけてはフトモモ科の SYAT SYAT が純林を形成し，海抜高に応じて樹高 が低くなり，3,800m から上の森林限界線の上では 30 $\mathrm{cm}$ 位の高さで群落をなしているのが見られた。高山 帯は Borneo buttercup (キンポウゲ類) が黄色の可憐 な花を咲かせていた。

キナバル山の Summit Plateau は花崗岩が露出して いる奇怪な状況を呈している。文献によると100万前は 水河に覆われていたものの, 水河の流出と共に堆積層 が流れて現在の基岩が露出したとある。花崗岩の隙間 には，スゲ類のイネ科や矮性のキク科の植物に混じっ て日本の高山にも見られるガンコウランの近縁種が花 を付けていた。

\section{5. 熱帯林の消失}

日本列島でゴルフ場開発が急激に増えているという 声が高まっても，依然として国土の約70\%が森林であ るという保護状態は変わらない。一方,「地球環境白書」 によると熱帯林は一年間に四国の面積ほどが消えてゆ き，一度伐採された跡地はアランアランに代表される イネ科植生におおわれ reforestation とは程遠い状況 
であると。しかし，自分の眼で熱帯林を見た事がない。 LANDSAT 衛星画像を用いた東南アジアの熱帯林管 理プロジェクトが進行しつつある今，この機会を逃し たらと参加した。日本では吉良元大阪市立大学教授を 中心としたIBP (International Biological Programme) というマレーシアはパソ一林での熱帯林の 生態研究をした業績があり, 多くの研究成果を挙げて いるにもかかわらず,「熱帯林は成長が速い, 密度が高 いので効率がよい」式の一般論で大規模な伐採が続い て,タイ, フィリピンなどの山地はもうハゲ山に等し い状況となっている。

ちなみに, 熱帯林の生産速度（1 年間に生産する植 物体の総量）は2.5 2.6 kg $/ \mathrm{m}^{2} ・$ 年 (dry weight) であ $\eta$, 日本の照葉樹林の $1.5 \sim 3.0 \mathrm{~kg} / \mathrm{m}^{2} \cdot$ 年 (dry weight) と大差ない生産力しかないのである。

伐採の主な要因は次の通りである。

(1) 焼畑農業

（2）木材生産のための伐採

(3) 薪炭用材としての伐採

(4) 農地開発のための伐採

伐採されても二次植生が成育すればよいという論理 もある。確かに二次林の生産速度は早いし, 伐採跡地 には換金植物により reforestationがおこなわれてい る。これらは $4 \sim 5$ 年で $20 \mathrm{~m}$ の高さになるユーカリ類 から, ゴム, アブラヤシ類である。

しかし，熱帯林本来の次の機能はどうなるかを考之 てみる必要がある。

1 ）薪炭林の供給と木材生産

2 ）土㙴・水資源の保全

3 ）炭酸ガスを吸収, 酸素を供給

4 ）生物種の保全

二次林が再生した地域は別として，ハゲ山にはしな いこと, 伐採跡地は植林するなど世界的な動きが出て 来てはいるが, 消失の速度には追い付けない状況であ る。

\section{6. 頂上}

空が白みを帯びて来た。Summit Plateauの花崗岩
上を黙々と歩く。懐中電灯を持っている手が寒さの中 でしびれて来た。誰かが, 凍傷になると言ったが笑う 人はいない。越智さんは（写真にあるように）タオル で顔を覆って，村井教授はタオルの煩かむりで風があ たらないようにしている。Abduhl は相変わらずマイ ペース，ガイドと後をノコノコ。

朝日が「山肌を紫色に染める」詩的なイメージが沸 いたと思ったら Low's Peakの頂上が見えてきた。山 小屋から列をなしていた登山客の誰もがホッとし，懐 中電灯を消し始めた。高度差 $100 \mathrm{~m}$ もないゴロゴロし た岩のコブの上が頂上であった。もう登りはない， 6 時10分, 頂上ではオーストラリア, カナダ, シンガポー ル, 国籍の関係もなく握手をし, 記念写真に入る。若 いシンガポールの女性が抱きついてきて，写真を撮ろ うという(住所も名前も聞いていなかったことが残念 でならない)。

15分位頂上に滞在していた一瞬，太陽が顔をのぞか せた。片隅にあった記録簿に記念のサインをして， あ

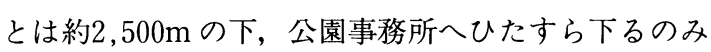
という安堵感の中, 写真- 1 は途中で撮った記念写真で ある。後はアグリシスター，はるか後方にドンキーイ ヤーが見えている。ものの本によると，「熱帯林を少し でも勉強し始めたら， 3 度は現地を歩かなくてはなら ない」とあった。残りの 2 回，どんなテーマをもって 再訪できるのやらと思いながらの下り道，公園事務所 では細村教授一家がビールで歓待してくれた。一気に 下った負担で腫れた足首をかばって歩いていると，毎 日お定まりのスコールが来た。海抜 $0 \mathrm{~m}$ の Kota Kinabaluへ一目散であった。

以上は，1991年 9 月 30 日から 10 月 7 日までの記録で ある。素晴らしい機会を紹介，また記事にするよう勧 めて下さった村井教授に梁く感謝申し上げます。

\section{引用文 献}

1）吉良竜夫：熱带林の生態, 1983.07 .20 , 人文書院 